\title{
Exploring an Expedient IMDA Reaction Approach to Construct the Guanacastepenes Core
}

\author{
Chuang-Chuang Li, ${ }^{\text {ta }}$ Xin-Hao Zhang, ${ }^{\mathrm{b}}$ Shuang Liang, ${ }^{\mathrm{a}}$ Zhi-Xiang Xie, ${ }^{\mathrm{a}}$ Jia-Hua \\ Chen, ${ }^{*^{a}}$ Yun-Dong Wu ${ }^{*^{a, b}}$ and Zhen Yang ${ }^{*^{a, c}}$
}

${ }^{a}$ Key Laboratory of Bioorganic Chemistry and Molecular Engineering of Ministry of Education, College of Chemistry, State Key Laboratory of Natural and Biomimetic Drugs, School of Pharmaceutical Science, and Laboratory of Chemical Genetics, Shenzhen Graduate School, Peking University, Beijing, 100871; ${ }^{b}$ Department of Chemistry, The Hong Kong University of Science and Technology, Clear Water Bay, Kowloon, Hong Kong, China; and ${ }^{c}$ VivoQuest, Inc.

711 Executive Blvd. Valley Cottage, NY, 10989 USA

zyang@pku.edu.cn

\section{Supporting Information}

\section{Table of Contents}

Page 2-14: General Information and synthetic procedure and spectra data for the syntheses of compounds $\mathbf{1 5}$ to 33.

Page15-17: 2D-NMR study for determination of relative stereochemistry of compound 34. 


\section{General Procedure:}

Unless noted otherwise, all oxygen and moisture-sensitive reactions were executed in flame-dried glasswares under a positive pressure of dry argon or nitrogen. The moisture sensitive solutions and anhydrous solvents were transferred via standard syringe or cannula. All commercial available reagents were used as received, and solvents were dried by standard methods under nitrogen atmosphere: THF and diethyl ether were distilled over $\mathrm{Na}-\mathrm{K}$ benzophenone; $\mathrm{CH}_{2} \mathrm{Cl}_{2}, \mathrm{Et}_{3} \mathrm{~N}$ and pyridine were distilled from $\mathrm{CaH}_{2}$. Purification of products was conducted by flash column chromatography on silica gel (200-300 mesh) purchased from Qing Dao Hai Yang Chemical Industry Co. Analytical TLC was performed using $0.25 \mathrm{~mm}$ Qing Dao silica gel $\mathrm{F}_{254}$ plates that were visualized by irradiation $(254 \mathrm{~nm})$ or by staining $\left(450 \mathrm{~mL}\right.$ of $95 \% \mathrm{EtOH}, 25 \mathrm{~mL}$ conc. $\mathrm{H}_{2} \mathrm{SO}_{4}, 15 \mathrm{~mL}$ acetic acid, and $25 \mathrm{~mL}$ anisaldehyde and 2, 4-dinitrophenylhydrazine). NMR spectra were obtained using 200 $\mathrm{MHz}$ or $300 \mathrm{MHz}$ Varian instrument and $400 \mathrm{MHz}$ Bruker instrument. Mass spectrometric data were obtained using ZAB-HS mass spectrometer.

\section{Preparation of Compound 15}

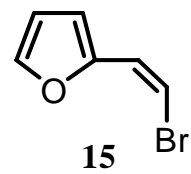

To a solution of $\mathrm{PPh}_{3}(26.2 \mathrm{~g}, 100 \mathrm{mmol})$ in $\mathrm{CH}_{2} \mathrm{Cl}_{2}(100 \mathrm{~mL})$ was added $\mathrm{CBr}_{4}(17.1$ $\mathrm{g}, 50 \mathrm{mmol})$ in one portion at $0^{0} \mathrm{C}$, after $10 \mathrm{~min}, \mathrm{Et}_{3} \mathrm{~N}(15 \mathrm{~mL})$ was added. ${ }^{1}$ After $5 \mathrm{~min}$, 2-furan-aldehyde 14 (2.4 g, $25 \mathrm{mmol})$ was added in dropwise, and the reaction mixture was stirred for $30 \mathrm{~min}$ at $0^{0} \mathrm{C}$. The reaction was worked up by addition hexane $(300 \mathrm{~mL})$, and the mixture was filtered through celite, and washed with hexane. The solvent was removed under vacuum and the residue dissolved in $\mathrm{Et}_{2} \mathrm{O}(200 \mathrm{~mL})$, and treated with $\mathrm{Pd}\left(\mathrm{PPh}_{3}\right)_{4}(865 \mathrm{mg}, 0.75 \mathrm{mmol})$ and $\mathrm{Bu}_{3} \mathrm{SnH}(8.01 \mathrm{~g}, 27.5 \mathrm{mmol})$ for $30 \mathrm{~min}$. The reaction mixture was first treated with aqueous solution of $\mathrm{KF}$, and then extracted with $\mathrm{Et}_{2} \mathrm{O}$. The extract was washed with $\mathrm{H}_{2} \mathrm{O}$, brine, dried over $\mathrm{Na}_{2} \mathrm{SO}_{4}$. The solvent was removed under vacuum and the residue was purified by flash chromatography with hexane to give cisvinyl bromide 15 (3.65 g, 83\% for two steps). ${ }^{1} \mathrm{H}-\mathrm{NMR}\left(300 \mathrm{MH}_{\mathrm{Z}}, \mathrm{CDCl}_{3}\right): \delta 7.45-7.44$ (m, 1H), $7.10(\mathrm{~d}, J=3.6 \mathrm{~Hz}, 1 \mathrm{H}), 7.07$ (d, $J=8.4 \mathrm{~Hz}, 1 \mathrm{H}), 6.49-6.48(\mathrm{~m}, 1 \mathrm{H}), 6.32(\mathrm{~d}, J=$ 
$8.1 \mathrm{~Hz}, 1 \mathrm{H}) ;{ }^{13} \mathrm{C}-\mathrm{NMR}\left(75 \mathrm{MH}_{\mathrm{Z}}, \mathrm{CDCl}_{3}\right): \delta=150.5,142.1,122.1,111.6,111.4,104.3$.

[Ref: (1) Corey, E. J.; Fuchs, P. L. Tetrahedron Lett. 1972, 3769. (2) Uenishi, J.; Kawahama, R.; Shiga, Y.; Yonemitsu, O.; Tsuji, J. Tetrahedron Lett. 1996, 37, 6759; (3) Uenishi, J.; Kawahama, R.; Shiga, Y.; Yonemitsu, O.; Tsuji, J. J. Org. Chem. 1996, 61, 5716.]

\section{Preparation of Compound 18}

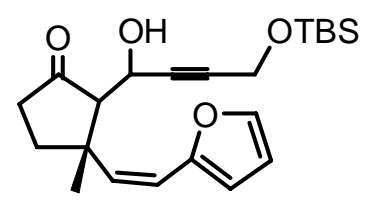

18

A solution of vinyl bromide $15(1.5 \mathrm{~g}, 8.7 \mathrm{mmol})$ in $\mathrm{Et}_{2} \mathrm{O}(15 \mathrm{~mL})$ was degassed by $\mathrm{N}_{2}$ for $15 \mathrm{~min}$ at room temperature, and then cooled to $-94^{\circ} \mathrm{C}$. To this solution was added dropwise a pre-cooled tert-butyl lithium $(1.5 \mathrm{M}, 11.6 \mathrm{~mL})$ in hexane during $30 \mathrm{~min}$, and then the reaction mixture was continually stirred at $-78^{\circ} \mathrm{C}$ for additional $30 \mathrm{~min}$. To this solution, a solution of $\mathrm{Bu}_{3} \mathrm{P}$ and $\mathrm{CuI}$ in $\mathrm{Et}_{2} \mathrm{O}$ [prepared by mixing $\mathrm{Bu}_{3} \mathrm{P}(8.7 \mathrm{mmol})$ and $\mathrm{CuI}(8.7 \mathrm{mmol})$ in $\left.\mathrm{Et}_{2} \mathrm{O}(20 \mathrm{~mL})\right]$ was added dropwise at $-78{ }^{\circ} \mathrm{C}$, and the resulted reaction mixture was then warmed to $-40^{\circ} \mathrm{C}$ for $10 \mathrm{~min}$. The reaction mixture was then recooled to $-78^{\circ} \mathrm{C}$, and a solution of $\mathrm{BF}_{3} \cdot \mathrm{Et}_{2} \mathrm{O}(1.3 \mathrm{~mL}, 8.7 \mathrm{mmol})$ in $\mathrm{Et}_{2} \mathrm{O}$ was added dropwise. After stirring at $-78^{\circ} \mathrm{C}$ for $20 \mathrm{~min}, 3$-methyl cyclopent-2-enone 16 (5 mmol) in $\mathrm{Et}_{2} \mathrm{O}(20 \mathrm{~mL})$ was introduced to the above solution dropwise during $30 \mathrm{~min}$, and the reaction mixture was stirred at $-78^{\circ} \mathrm{C}$ for another $30 \mathrm{~min}$. To this solution, aldehyde 17 $(15 \mathrm{mmol})$ in $\mathrm{Et}_{2} \mathrm{O}(20 \mathrm{~mL})$ was added in dropwise during 30min, and the resulted reaction mixture was kept stirring for an additional hour at the same temperature and for an additional hour at room temperature. The reaction was worked up by addition of aqueous $\mathrm{NH}_{4} \mathrm{Cl}(30 \mathrm{~mL})$, and extracted with $\mathrm{Et}_{2} \mathrm{O}(3 \times 70 \mathrm{~mL})$. The extract was washed with water and brine, and dried over anhydrous $\mathrm{MgSO}_{4}$. The solvent was removed under Vacuum, and the residue was purified by flash chromatography to give 18 (1.3 g, 67\% yield) (The yields were calculated based on the enone used). Since product $\mathbf{1 8}$ is a mixture of diastereoisomers, so its $\mathrm{H}-\mathrm{NMR}$ and $\mathrm{C}^{13}$-NMR are difficult to give the assignment; $\mathrm{MS}\left[\mathrm{C}_{22} \mathrm{H}_{32} \mathrm{O}_{4} \mathrm{Si}\right.$ ], (EI) m/z $\left(\mathrm{M}^{+}\right)$, calcd 388, found 388 .

(The acetylenic aldehyde 17 was prepared by the procedure developed by Journet, M.;Cai, 
D.;DiMichele, L.M.; Larsen, R.D. Tetrahedron Lett. 1998, 39, 6427.)

Preparation of Compound 11

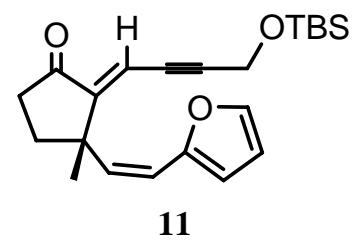

To a solution of $18(388 \mathrm{mg}, 1 \mathrm{mmol})$ in $\mathrm{CH}_{2} \mathrm{Cl}_{2}(20 \mathrm{~mL})$ was added DMAP (610 $\mathrm{mg}, 5 \mathrm{mmol})$ and $\mathrm{MsCl}(285 \mathrm{mg}, 2.5 \mathrm{mmol})$ at room temperature, and the reaction mixture was stirred at same temperature for 1 hour. The reaction mixture was diluted with $\mathrm{Et}_{2} \mathrm{O}(100 \mathrm{~mL})$, and the organic phase was washed with water, brine, and dried over $\mathrm{MgSO}_{4}$. The solvent was removed under vacuum and the residue was purified by flash chromatography to give compound 11 (315 mg, in 85\% yield); ${ }^{1} \mathrm{H}-\mathrm{NMR}\left(300 \mathrm{MH}_{\mathrm{Z}}\right.$, $\left.\mathrm{CDCl}_{3}\right) \delta 7.22(\mathrm{~d}, J=1.5 \mathrm{~Hz}, 1 \mathrm{H}), 6.28-6.24(\mathrm{~m}, 2 \mathrm{H}), 6.13-6.08(\mathrm{~m}, 2 \mathrm{H}), 5.86(\mathrm{~d}, J=$ $12.3 \mathrm{~Hz}, 1 \mathrm{H}), 4.45$ (d, J=2.1 Hz, 2H), 2.50-2.24 (m, 3H), 1.96-1.90 (m, 1H), 1.49 (s, 3H), $0.88(\mathrm{~s}, 9 \mathrm{H}), 0.08(\mathrm{~s}, 6 \mathrm{H}) ;{ }^{13} \mathrm{C}-\mathrm{NMR}\left(75 \mathrm{MH}_{\mathrm{Z}}, \mathrm{CDCl}_{3}\right) \delta 206.0,155.5,151.5,142.1$, 136.1, 116.5, 111.0, 110.8, 110.7, 102.2, 81.8, 52.2, 44.2, 35.9, 34.5, 28.2, 25.7, 18.2, -5.3; MS $\left[\mathrm{C}_{22} \mathrm{H}_{30} \mathrm{O}_{3} \mathrm{Si}\right],(\mathrm{EI}) \mathrm{m} / \mathrm{z}\left(\mathrm{M}^{+}\right)$, calcd 370 , found 370 .

\section{Preparation of Compound 20}<smiles>CC12C=CC3=Cc4c(O)ccc(c4CO)C=C3C=CC1(C)C(=O)CC2</smiles>

A solution $11(37.0 \mathrm{mg}, 0.10 \mathrm{mmol})$ was dissolved in toluene $(10 \mathrm{~mL})$, and the mixture was refluxed at $120{ }^{\circ} \mathrm{C}$ for $12 \mathrm{~h}$. The solvent was removed under vacuum and the residue was purified by chromatography on silica gel to give 20 ( $31.5 \mathrm{mg}$, in $85 \%$ yield); ${ }^{1} \mathrm{H}-\mathrm{NMR}\left(300 \mathrm{MH}_{\mathrm{Z}}, \mathrm{CDCl}_{3}\right): \delta 9.12(\mathrm{~s}, 1 \mathrm{H}), 7.35$ (s, 1H), $7.18(\mathrm{~d}, J=8.4 \mathrm{~Hz}, 1 \mathrm{H}), 6.93$ $(\mathrm{d}, J=8.4 \mathrm{~Hz}, 1 \mathrm{H}), 6.48(\mathrm{~d}, J=10.8 \mathrm{~Hz}, 1 \mathrm{H}), 5.69$ (d, $J=10.8 \mathrm{~Hz}, 1 \mathrm{H}), 5.34(\mathrm{~d}, J=13.5$ $\mathrm{Hz}, 1 \mathrm{H}), 5.10(\mathrm{~d}, J=13.5 \mathrm{~Hz}, 1 \mathrm{H}), 2.50(\mathrm{t}, J=8.1 \mathrm{~Hz}, 2 \mathrm{H}), 2.09$ (t, $J=8.1 \mathrm{~Hz}, 2 \mathrm{H}), 0.94$ (s, $12 \mathrm{H}), 0.19$ (d, $J=6.3 \mathrm{~Hz}, 6 \mathrm{H}) ;{ }^{13} \mathrm{C}-\mathrm{NMR}\left(100 \mathrm{MH}_{\mathrm{Z}}, \mathrm{CDCl}_{3}\right): \delta 206.0,155.9,142.4$, $137.9,131.8,130.3,129.7,128.6,124.8,122.5,118.6,63.1,41.9,36.5,35.8,25.7,22.9$, 18.1, -5.5; MS $\left[\mathrm{C}_{22} \mathrm{H}_{30} \mathrm{O}_{3} \mathrm{Si}\right]$, (EI) $\mathrm{m} / \mathrm{z}\left(\mathrm{M}^{+}\right)$, calcd 370, found 370 .

\section{Preparation of Compound 11a}




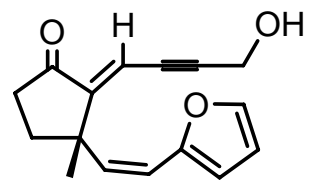

11a

To a solution of $11(260 \mathrm{mg}, 0.7 \mathrm{mmol})$ in $\mathrm{CH}_{3} \mathrm{CN}(10 \mathrm{~mL})$ was added pyridine (1 $\mathrm{mL})$ and $42 \%$ aqueous $\mathrm{HF}$ solution $(1 \mathrm{~mL})$ at room temperature, and the reaction mixture was stirred at same temperature for 1 hour. The reaction was worked up by addition of $\mathrm{Et}_{2} \mathrm{O}(100 \mathrm{~mL})$, and the organic phase was washed with water, brine, and dried over $\mathrm{MgSO}_{4}$. The solvent was removed under vacuum and the residue was purified by flash chromatography to give 11a (166 mg, in 95\% yield); ${ }^{1} \mathrm{H}-\mathrm{NMR}\left(300 \mathrm{MH}_{\mathrm{Z}}, \mathrm{CDCl}_{3}\right): \delta 7.25$ (d, $J=1.2 \mathrm{~Hz}, 1 \mathrm{H}), 6.31-6.28$ (m, 2H), 6.18-6.14 (m, 2H), 5.89 (d, $J=12.6 \mathrm{~Hz}, 1 \mathrm{H}), 4.43$ $(\mathrm{d}, J=2.1 \mathrm{~Hz}, 1 \mathrm{H}), 2.60-2.24(\mathrm{~m}, 3 \mathrm{H}), 2.02-1.90(\mathrm{~m}, 1 \mathrm{H}), 1.51(\mathrm{~s}, 3 \mathrm{H}) ;{ }^{13} \mathrm{C}-\mathrm{NMR}(75$ $\left.\mathrm{MH}_{\mathrm{Z}}, \mathrm{CDCl}_{3}\right): \delta 206.8,155.7,151.4,142.1,135.9,116.4,110.9,110.8,110.8,102.1,82.3$, $51.3,44.2,35.9,34.4,28.1$.

\section{Preparation of Compound 21}

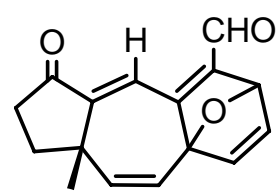

21

To a solution of 11a $(150 \mathrm{mg}, 0.58 \mathrm{mmol})$ in $\mathrm{CH}_{2} \mathrm{Cl}_{2}(10 \mathrm{~mL})$ was added DessMartin periodinane $(424 \mathrm{mg}, 1.0 \mathrm{mmol})$ in one portion at room temperature, and the reaction mixture was stirred at room temperature for $1 \mathrm{~h}$. The reaction was worked up by addition of petroleum ether $(50 \mathrm{~mL})$, and the formed white solid was removed by filtration through celite and washed with $\mathrm{Et}_{2} \mathrm{O}$. The filtrate was stirred at room temperature for $12 \mathrm{~h}$, and the reaction mixture was then concentrated. The residue was purified by flash column chromatography to give 21 (126 mg, in 84\% yield); ${ }^{1} \mathrm{H}-\mathrm{NMR}$ $\left(300 \mathrm{MH}_{\mathrm{Z}}, \mathrm{CDCl}_{3}\right): \delta 10.10(\mathrm{~s}, 1 \mathrm{H}), 7.47(\mathrm{~s}, 1 \mathrm{H}), 7.22\left(\mathrm{dd}, J_{1}=1.8, J_{2}=5.1 \mathrm{~Hz}, 1 \mathrm{H}\right)$, $6.83(\mathrm{~d}, J=5.4 \mathrm{~Hz}, 1 \mathrm{H}), 6.08(\mathrm{~d}, J=12.0 \mathrm{~Hz}, 1 \mathrm{H}), 5.88(\mathrm{~d}, J=12.0 \mathrm{~Hz}, 1 \mathrm{H}), 5.72(\mathrm{~d}, J=$ $2.1 \mathrm{~Hz}, 1 \mathrm{H}), 2.58-2.52(\mathrm{~m}, 2 \mathrm{H}), 2.11-2.06(\mathrm{~m}, 2 \mathrm{H}), 1.38(\mathrm{~s}, 3 \mathrm{H}) ;{ }^{13} \mathrm{C}-\mathrm{NMR}\left(75 \mathrm{MH}_{\mathrm{Z}}\right.$, $\left.\mathrm{CDCl}_{3}\right): \delta 205.5,183.6,163.8,156.3,149.9,146.0,145.3,139.9,121.1,118.3,91.8,79.7$, 46.6, 34.5, 33.6, 29.8. MS [ $\left.\mathrm{C}_{16} \mathrm{H}_{14} \mathrm{O}_{3}\right]$, (EI) $\mathrm{m} / \mathrm{z}\left(\mathrm{M}^{+}\right)$, calcd 254, found 254 . 


\section{Preparation of Compound 22a}

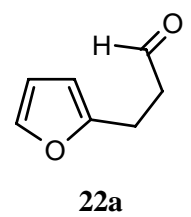

To a solution of $22(10.0 \mathrm{~g}, 81.97 \mathrm{mmol})$ in dried distilled THF $(150 \mathrm{ml})$ was added Lindlar catalyst $(500 \mathrm{mg})$, and the mixture was then stirred balloon pressure of $\mathrm{H}_{2}$ at $35^{\circ} \mathrm{C}$ for $24 \mathrm{~h}$. The reaction was filtered through a celit and the filtrate was concentrated under vacuum. The residues was dissolved in freshly distilled $\mathrm{CH}_{2} \mathrm{Cl}_{2}(100 \mathrm{ml})$, and treated with Dess-Martin periodinane, $(17.0 \mathrm{~g}, 40 \mathrm{mmol})$, and the mixture was stirred at room temperature for $30 \mathrm{~min}$. The reaction mixture was quenched with saturated aqueous solution of $\mathrm{Na}_{2} \mathrm{~S}_{2} \mathrm{O}_{3}(5 \mathrm{~mL})$, then washed with $\mathrm{NaHCO}_{3}(5 \mathrm{~mL})$, and finally dried over anhydrous $\mathrm{Na}_{2} \mathrm{SO}_{4}$. The solvent was removed and the residue was purified by flash chromatography (hexanes/EtOAc $=20 / 1)$ to give 22a ( $9.05 \mathrm{~g}$, in $89 \%$ yield for 2 steps) as a colorless oil. ${ }^{1} \mathrm{H}-\mathrm{NMR}\left(300 \mathrm{MH}_{\mathrm{Z}}, \mathrm{CDCl}_{3}\right): \delta 9.75(\mathrm{t}, J=1.2 \mathrm{~Hz}, 1 \mathrm{H}), 7.28(\mathrm{~d}, J=1.5$ $\mathrm{Hz}, 1 \mathrm{H}), 6.26\left(\mathrm{dd}, J_{1}=1.8 \mathrm{~Hz}, J_{2}=3.0 \mathrm{~Hz}, 1 \mathrm{H}\right), 6.01-5.99(\mathrm{~m}, 1 \mathrm{H}), 2.94(\mathrm{t}, J=7.2 \mathrm{~Hz}$, 2H), $2.75(\mathrm{t}, J=7.2 \mathrm{~Hz}, 2 \mathrm{H}) ;{ }^{13} \mathrm{C}-\mathrm{NMR}\left(75 \mathrm{MH}_{\mathrm{Z}}, \mathrm{CDCl}_{3}\right) \delta 200.7,153.7,140.9,109.9$, 105.1, 41.4, 20.3.

\section{Preparation of Compound 23}<smiles>BrC(Br)=CCCc1ccco1</smiles>

23

To an ice-cooled solution of carbon tetrabromide (35.9 g, $105 \mathrm{mmol})$ in dry methylene chloride $(200 \mathrm{~mL})$ was added triphenylphosphine $(55.0 \mathrm{~g}, 210 \mathrm{mmol})$ and the resulting orange solution was stirred in an ice-bath for $30 \mathrm{~min}$. The aldehyde 22a prepared in the previous step in dry $\mathrm{CH}_{2} \mathrm{Cl}_{2}(40 \mathrm{~mL})$ was added in dropwise at the same temperature. The mixture turned deep red. After stirring at $0{ }^{\circ} \mathrm{C}$ for $10 \mathrm{~min}$, the reaction was quenched with water. Extractive workup with ether and column chromatography $($ EtOAc/hexanes $=5 / 95)$ gave $5.6 \mathrm{~g}(86 \%)$ of the desired dibromide 23 as colorless oil; ${ }^{1} \mathrm{H}$ $\operatorname{NMR}\left(300 \mathrm{MH}_{\mathrm{Z}}, \mathrm{CDCl}_{3}\right): \delta 7.3\left(\mathrm{dd}, J_{1}=0.9 \mathrm{~Hz}, J_{2}=1.8 \mathrm{~Hz}, 1 \mathrm{H}\right), 6.42(\mathrm{t}, J=7.2 \mathrm{~Hz}$, $1 \mathrm{H}), 6.31\left(\mathrm{dd}, J_{1}=1.8 \mathrm{~Hz}, J_{2}=3.0 \mathrm{~Hz}, 1 \mathrm{H}\right), 6.04-6.03(\mathrm{~m}, 1 \mathrm{H}), 2.75(\mathrm{t}, J=7.2 \mathrm{~Hz}, 1 \mathrm{H})$, 2.48-2.40 (m, 2H); ${ }^{13} \mathrm{C}-\mathrm{NMR}\left(75 \mathrm{MH}_{\mathrm{Z}}, \mathrm{CDCl}_{3}\right): \delta 154.1,141.3,137.2,110.2,105.5,89.7$, 
31.5, 26.1; MS [ $\left.\mathrm{C}_{8} \mathrm{H}_{8} \mathrm{Br}_{2} \mathrm{O}\right],(\mathrm{EI}) \mathrm{m} / \mathrm{z}\left(\mathrm{M}^{+}\right)$, calcd 278, found 278.

\section{Preparation of Compound 24}<smiles>CCOC(=O)CCCc1ccco1</smiles>

To a solution of dibromide $23(10.8 \mathrm{~g}, 38.8 \mathrm{mmol})$ in dry $\mathrm{THF}(60 \mathrm{ml})$ at $-78^{\circ} \mathrm{C}$ was added $n$-BuLi $(38.8 \mathrm{~mL}, 97 \mathrm{mmol})$ under nitrogen, and the mixture was stirred at same temperature for $30 \mathrm{~min}$. and mixture at $0^{\circ} \mathrm{C}$ for an additional hour. To this solution was added a solution of ethyl chloroformate $(4.34 \mathrm{~g}, 40 \mathrm{mmol})$ in dry THF $(13 \mathrm{ml})$ in dropwise at $-78^{\circ} \mathrm{C}$, and the mixture was warmed up to $-20^{\circ} \mathrm{C}$, and stirred for 2 hours at the same temperature. The reaction mixture was first quenched with aqueous $\mathrm{NH}_{4} \mathrm{Cl}$, then the extracted with ether $(3 \times 100 \mathrm{~mL})$, and dried over $\mathrm{Na}_{2} \mathrm{SO}_{4}$. The solvent was removed under vacuum and the residue was purified by chromatography on silica gel (EtOAc/ $\mathrm{PE}=1 / 10)$ to give compound $24(6.41 \mathrm{~g}$, in $85 \%$ yield $) .{ }^{1} \mathrm{H}-\mathrm{NMR}\left(300 \mathrm{MH}_{\mathrm{Z}}, \mathrm{CDCl}_{3}\right)$ : $\delta$ $7.31(\mathrm{~m}, 1 \mathrm{H}), 6.28(\mathrm{~d}, J=3.0 \mathrm{~Hz}, 1 \mathrm{H}), 6.10(\mathrm{~d}, J=4.8 \mathrm{~Hz}, 1 \mathrm{H}), 4.26$ (q, $J=10.8 \mathrm{~Hz}, 2 \mathrm{H})$, $2.91(\mathrm{t}, J=10.8 \mathrm{~Hz}, 2 \mathrm{H}), 2.65(\mathrm{t}, J=10.8 \mathrm{~Hz}, 2 \mathrm{H}), 1.29(\mathrm{t}, J=10.8 \mathrm{~Hz}, 3 \mathrm{H}) ;{ }^{13} \mathrm{C}-\mathrm{NMR}$ $\left(75 \mathrm{MH}_{\mathrm{Z}}, \mathrm{CDCl}_{3}\right): \delta 153.5,152.9,141.4,110.2,105.9,87.4,73.56,61.7,26.3,17.8,13.9$; MS $\left[\mathrm{C}_{11} \mathrm{H}_{12} \mathrm{O}_{3}\right],(\mathrm{EI}) \mathrm{m} / \mathrm{z}\left(\mathrm{M}^{+}\right)$, calcd 192, found 192.

\section{Preparation of Compound 25}

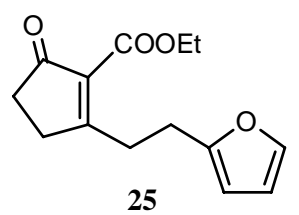

To a stirring solution of [(1-ethoxycyclopropyl)-oxy]-trimethyl silane $(13.2 \mathrm{~mL}$, $66 \mathrm{mmol})$ in ether $(8.0 \mathrm{~mL})$ was added $\mathrm{ZnCl}_{2}(1 \mathrm{M}$ solution, $49.5 \mathrm{~mL}, 49.5 \mathrm{mmol})$ via syringe in one portion at room temperature. The mixture was first sonicated for $40 \mathrm{~min}$. and then cooled to $0^{\circ} \mathrm{C}$. To this solution was added sequentially $\mathrm{CuBr} \mathrm{Me}_{2} \mathrm{~S}(680 \mathrm{mg})$ and acetylenic ester $24(6.36 \mathrm{~g}, 33 \mathrm{mmol})$ in THF $(60 \mathrm{~mL})$ and HMPA $(11.5 \mathrm{~mL})$, and the mixture was allowed to stir at $0^{\circ} \mathrm{C} 5 \mathrm{~min}$. and then warmed up to $25^{\circ} \mathrm{C}$ for 4 hours. The reaction was quenched by addition of saturated $\mathrm{NH}_{4} \mathrm{Cl}$ solution $(50 \mathrm{~mL})$, and the mixture was extracted ether ( $3 \times 100 \mathrm{ML})$. The organic phase was washed with $\mathrm{H}_{2} \mathrm{O}$, brine, and 
dried over $\mathrm{Na}_{2} \mathrm{SO}_{4}$. The solvent was removed under vacuum and the residue purified by flash chromatography on silica gel (EtOAc/ $\mathrm{PE}=1 / 10)$ to give compound 25 ( $4.6 \mathrm{~g}$, in 56\% yield); ${ }^{1} \mathrm{H}-\mathrm{NMR}\left(300 \mathrm{MH}_{\mathrm{Z}}, \mathrm{CDCl}_{3}\right): \delta 7.33\left(\mathrm{dd}, J_{1}=0.9 \mathrm{~Hz}, J_{2}=1.8 \mathrm{~Hz}, 1 \mathrm{H}\right), 6.30$ (dd, $\left.J_{1}=1.8 \mathrm{~Hz}, J_{2}=3.0 \mathrm{~Hz}, 1 \mathrm{H}\right), 6.06\left(\mathrm{dd}, J_{1}=0.9 \mathrm{~Hz}, J_{2}=3.0 \mathrm{~Hz}, 1 \mathrm{H}\right), 4.35(\mathrm{q}, J=7.2 \mathrm{~Hz}$, 2H), $3.11(\mathrm{t}, J=7.8 \mathrm{~Hz}, 2 \mathrm{H}), 2.97(\mathrm{t}, J=7.2 \mathrm{~Hz}, 2 \mathrm{H}), 2.61-2.57$ (m, 2H), 2.48-2.44 (m, 2H), $1.35(\mathrm{t}, J=7.2 \mathrm{~Hz}, 3 \mathrm{H}) ;{ }^{13} \mathrm{C}-\mathrm{NMR}\left(75 \mathrm{MH}_{\mathrm{Z}}, \mathrm{CDCl}_{3}\right): \delta 203.5,185.8,162.9,153.4$, $141.2,132.9,110.2,105.7,60.7,34.8,30.9,30.2,25.8,14.0 ; \mathrm{MS}\left[\mathrm{C}_{14} \mathrm{H}_{16} \mathrm{O}_{4}\right],(\mathrm{EI}) \mathrm{m} / \mathrm{z}$ $\left(\mathrm{M}^{+}\right)$, calcd 248 , found 248 .

\section{Preparation of compound 26}<smiles>CCOC(=O)C1C(=O)CCC1(C)CCc1ccco1</smiles>

To a stirred solution of $\mathrm{CuI}(1.15 \mathrm{~g}, 6 \mathrm{mmol})$ in THF was added $\mathrm{PBu}_{3}(1.5 \mathrm{~mL}, 6$ mmol) at room temperature and the colorless solution was obtained after stirring for 20 min. To this solution was added $\mathrm{MeMgCl}(3 \mathrm{M}$ solution, $2.0 \mathrm{~mL}, 6 \mathrm{mmol})$ at $-78^{\circ} \mathrm{C}$ in dropwise and the reaction mixture was slowly warmed up to $-30^{\circ} \mathrm{C}$. After cooling back to $-78^{\circ} \mathrm{C}, \mathrm{BF}_{3} \cdot \mathrm{Et}_{2} \mathrm{O}(6 \mathrm{mmol})$ was added, and the reaction mixture was stirred at same temperature for $20 \mathrm{~min}$. To this solution was added enone $25(1.0 \mathrm{~g}, 4.0 \mathrm{mmol})$ in THF (10 $\mathrm{mL}$ ), and the reaction mixture was stirred at same temperature for $10 \mathrm{~min}$. The reaction was quenched with saturated $\mathrm{NH}_{4} \mathrm{Cl}(5 \mathrm{~mL})$, and the mixture was extracted with ether (3 x $30 \mathrm{ml}$ ). The organic phase was washed with $\mathrm{H}_{2} \mathrm{O}$, brine, and dried over $\mathrm{Na}_{2} \mathrm{SO}_{4}$. The solvent was removed under vacuum and the residue was purified by chromatography on silica gel $($ EtOAc/PE=1/10) to give compound 26 (960 mg, in 90\% yield); Due to product contains three isomers, the assignment for the $\mathrm{H}^{1}$-NMR and $\mathrm{C}^{13}$-NMR was omitted; MS $\left[\mathrm{C}_{15} \mathrm{H}_{20} \mathrm{O}_{4}\right],(\mathrm{EI}) \mathrm{m} / \mathrm{z}\left(\mathrm{M}^{+}\right)$, calcd 264, found 264 .
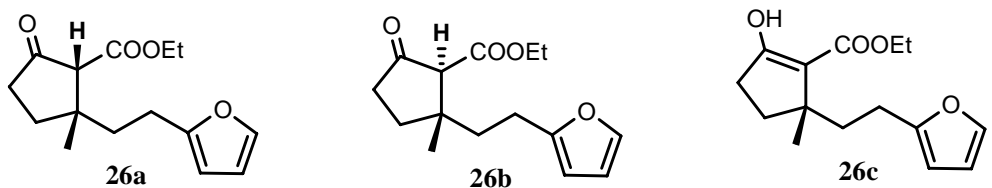


\section{Preparation of Compound 27}

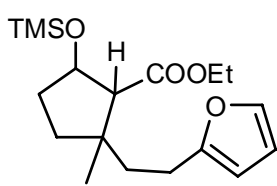

27

To a stirred solution of $26(860 \mathrm{mg}, 3.26 \mathrm{mmol})$ in absolute methanol $(20 \mathrm{~mL})$ was added $\mathrm{NaBH}_{4}(148 \mathrm{mg}, 3.9 \mathrm{mmol})$ at $-20^{\circ} \mathrm{C}$, and the mixture was stirred for $20 \mathrm{~min}$ at the same temperature. The mixture was diluted with ether $(150 \mathrm{~mL})$, then washed with brine, and dried over $\mathrm{Na}_{2} \mathrm{SO}_{4}$. The solvent was removed under vacuum, and the residue was dissolved in $\mathrm{CH}_{2} \mathrm{Cl}_{2}(10 \mathrm{~mL})$. To this solution was added 2,6-lutidine $(0.44 \mathrm{~mL}$, $5 \mathrm{mmol})$ and TMSOTf $(0.71 \mathrm{~mL}, 4 \mathrm{mmol})$ at $-30^{\circ} \mathrm{C}$, and the reaction mixture was stirred at same temperature for 1 hour. Then reaction was quenched by saturated aqueous $\mathrm{NH}_{4} \mathrm{Cl}$ $(5 \mathrm{~mL})$ at $-30^{\circ} \mathrm{C}$, and the mixture was then diluted with water $(20 \mathrm{~mL})$, and extracted with $\mathrm{Et}_{2} \mathrm{O}(3 \times 30 \mathrm{~mL})$. The organic phase was washed with brine $(30 \mathrm{~mL})$, and dried over $\mathrm{Na}_{2} \mathrm{SO}_{4}$. The solvent was removed under vacuum and the residue was purified by flash chromatography on silica gel $(\mathrm{EtOAc} / \mathrm{PE}=1 / 20)$ to give compound $27(810 \mathrm{mg}$, in $79 \%$ yield for two steps); ${ }^{1} \mathrm{H}-\mathrm{NMR}\left(300 \mathrm{MH}_{\mathrm{Z}}, \mathrm{CDCl}_{3}\right): \delta 7.30(\mathrm{br}, 1 \mathrm{H}), 6.27(\mathrm{br}, 1 \mathrm{H})$, $5.99(\mathrm{~d}, J=3.6 \mathrm{~Hz}, 1 \mathrm{H}), 4.54-4.52$ (m, 1H), 4.16-4.10 (m, 2H), 2.67-2.04 (m, 3H), 2.01$1.39(\mathrm{~m}, 6 \mathrm{H}), 1.31(\mathrm{t}, J=7.2 \mathrm{~Hz}, 3 \mathrm{H}), 1.24(\mathrm{~s}, 3 \mathrm{H}), 0.09(\mathrm{~s}, 9 \mathrm{H}) ;{ }^{13} \mathrm{C}-\mathrm{NMR}\left(75 \mathrm{MH}_{\mathrm{Z}}\right.$, $\left.\mathrm{CDCl}_{3}\right): \delta 171.3,156.3,140.6,110.1,104.4,74.5,59.5,59.4,43.3,40.8,37.2,33.3,23.6$, $21.9,14.3,-0.1$.

\section{Preparation of Compound 28}

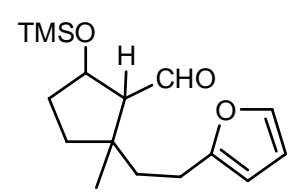

28

The compound $27(810 \mathrm{mg}, 2.40 \mathrm{mmol})$ was dissolved in $\mathrm{CH}_{2} \mathrm{Cl}_{2}(10 \mathrm{~mL})$, and the solution was cooled to $-78^{\circ} \mathrm{C}$. To this solution was added diisobutylaluminium hydride (DIBAL, 1.0 M in toluene, $0.6 \mathrm{~mL}, 0.66 \mathrm{mmol}$ ), and the reaction mixture was stirred at same temperature for 2 hours. The reaction was quenched by slow addition of $\mathrm{MeOH}(1 \mathrm{~mL})$ at $-78^{\circ} \mathrm{C}$, and the reaction mixture was allowed to slowly warm up to room temperature, then a saturated solution of Rochelle salt $(10 \mathrm{~mL})$ was added. The mixture 
was stirred until two clear phases were observed. The mixture was first extracted with $\mathrm{Et}_{2} \mathrm{O}(3 \times 50 \mathrm{~mL})$, and the combined organic layer was dried over $\mathrm{Na}_{2} \mathrm{SO}_{4}$. The solvent was removed under vacuum, and the residue was then dissolved in anhydrous $\mathrm{CH}_{2} \mathrm{Cl}_{2}$ (100ml). To this solution was added Dess-Martin periodinane (1.53 g, $2.40 \mathrm{mmol})$, and the mixture was stirred at room temperature for $30 \mathrm{~min}$. The reaction was first quenched with saturated $\mathrm{Na}_{2} \mathrm{~S}_{2} \mathrm{O}_{3}(5 \mathrm{~mL})$ and extracted with ethyl acetate $(3 \times 50 \mathrm{~mL})$. The organic phase was washed with aqueous $\mathrm{NaHCO}_{3}(30 \mathrm{~mL})$, and dried over anhydrous $\mathrm{Na}_{2} \mathrm{SO}_{4}$. The solvent was removed under vacuum and the residue was purified by flash chromatography $(\mathrm{PE} / \mathrm{EtOAc}=20 / 1)$ to give $28(456 \mathrm{mg}$, in $65 \%$ yield for two steps $) ;{ }^{1} \mathrm{H}$ NMR $\left(300 \mathrm{MH}_{\mathrm{z}}, \mathrm{CDCl}_{3}\right): \delta 9.88(\mathrm{~d}, J=7.2 \mathrm{~Hz}, 1 \mathrm{H}), 7.31(\mathrm{~s}, 1 \mathrm{H}), 6.29(\mathrm{~d}, J=1.8 \mathrm{~Hz}$, $1 \mathrm{H}), 6.00(\mathrm{~d}, J=3.0 \mathrm{~Hz}, 1 \mathrm{H}), 4.61-4.59(\mathrm{~m}, 1 \mathrm{H}), 2.68-2.28(\mathrm{~m}, 2 \mathrm{H}), 2.28-2.25(\mathrm{~m}, 1 \mathrm{H})$, 2.05-1.56 (m, 6H), $1.30(\mathrm{~s}, 3 \mathrm{H}), 0.13(\mathrm{~s}, 9 \mathrm{H}) ;{ }^{13} \mathrm{C}-\mathrm{NMR}\left(75 \mathrm{MH}_{\mathrm{Z}}, \mathrm{CDCl}_{3}\right): \delta 206.1$, $155.9,140.7,110.1,104.5,75.6,63.9,44.9,41.4,37.9,34.8,23.5,22.6,-0.2$; MS $\left[\mathrm{C}_{16} \mathrm{H}_{26} \mathrm{O}_{3} \mathrm{Si}\right]$, (EI) $\mathrm{m} / \mathrm{z}\left(\mathrm{M}^{+}\right)$, calcd 294, found 294.

\section{Preparation of Compound 29}

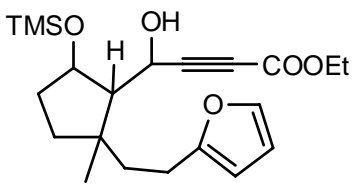

29

To a solution of $(0.33 \mathrm{~mL} 2.50 \mathrm{mmol})$ of diisopropylamine in THF $(8 \mathrm{~mL})$ was added $\mathrm{n}$-BuLi $\left(2.5 \mathrm{M}\right.$ solution, $0.8 \mathrm{~mL}(2.0 \mathrm{mmol})$ in hexane at $-78{ }^{\circ} \mathrm{C}$, and the mixture was stirred at same temperature for $30 \mathrm{~min}$. To this solution was added ethyl propiolate $(0.20 \mathrm{~mL}, 2.0 \mathrm{mmol})$ in THF $(2.0 \mathrm{~mL})$ during $5 \mathrm{~min}$. and the reaction mixture was stirred at same temperature for $20 \mathrm{~min}$. To this solution was added aldehyde $\mathbf{2 8}$ (456 $\mathrm{mg}, 1.55$ $\mathrm{mmol})$ in THF $(2 \mathrm{~mL})$ in dropwise, and the mixture was stirred for another $20 \mathrm{~min}$. The reaction was quenched by addition of a saturated aqueous $\mathrm{NH}_{4} \mathrm{Cl}(5 \mathrm{~mL})$ at $-78^{\circ} \mathrm{C}$, and the mixture was then allowed to warm up to room temperature. After addition of water $(20 \mathrm{~mL})$, the mixture was extracted with $\mathrm{Et}_{2} \mathrm{O}(3 \mathrm{x} 50 \mathrm{~mL})$, and the combined organic layer was washed with brine $(30 \mathrm{~mL})$, and dried over $\mathrm{Na}_{2} \mathrm{SO}_{4}$. The solvent was removed under vacuum and the residue was purified by flash chromatography on silica gel (EtOAc/PE=1/10) to give compound 29 (559 mg, in 92\% yield). ${ }^{1} \mathrm{H}-\mathrm{NMR}$ (300 $\mathrm{MH}_{\mathrm{Z}}$, 
$\left.\mathrm{CDCl}_{3}\right): \delta 7.29\left(\mathrm{dd}, J_{1}=0.6 \mathrm{~Hz}, J_{2}=1.8 \mathrm{~Hz}, 1 \mathrm{H}\right), 6.27\left(\mathrm{dd}, J_{1}=2.1 \mathrm{~Hz}, J_{2}=3.3 \mathrm{~Hz}, 1 \mathrm{H}\right)$, $5.97\left(\mathrm{dd}, J_{1}=0.9 \mathrm{~Hz}, J_{2}=3.3 \mathrm{~Hz}, 1 \mathrm{H}\right), 4.75\left(\mathrm{dd}, J_{1}=6.3 \mathrm{~Hz}, J_{2}=9.3 \mathrm{~Hz}, 1 \mathrm{H}\right), 4.47-4.44$ $(\mathrm{m}, 1 \mathrm{H}), 4.26(\mathrm{q}, J=7.2 \mathrm{~Hz}, 2 \mathrm{H}), 2.65-2.61(\mathrm{~m}, 2 \mathrm{H}), 2.35$ (d, $J=6.0 \mathrm{~Hz}, 1 \mathrm{H}), 1.95-1.85$ $(\mathrm{m}, 2 \mathrm{H}), 1.77-1.32(\mathrm{~m}, 4 \mathrm{H}), 1.30(\mathrm{t}, J=7.2 \mathrm{~Hz}, 3 \mathrm{H}), 1.22(\mathrm{~s}, 3 \mathrm{H}), 0.12(\mathrm{~s}, 9 \mathrm{H}) ;{ }^{13} \mathrm{C}-$ NMR (75 $\left.\mathrm{MH}_{Z}, \mathrm{CDCl}_{3}\right): \delta 156.7,153.5,140.6,110.1,104.3,88.8,76.6,76.5,61.9,61.9$, 57.6, 42.7 , 41.7, 37.5, 33.6, 23.8, 22.8, 13.9, 0.1; MS $\left[\mathrm{C}_{21} \mathrm{H}_{32} \mathrm{O}_{5} \mathrm{Si}\right],(\mathrm{EI}) \mathrm{m} / \mathrm{z}\left(\mathrm{M}^{+}\right)$, calcd 393, found 392.

\section{Preparation of Compound 29a}

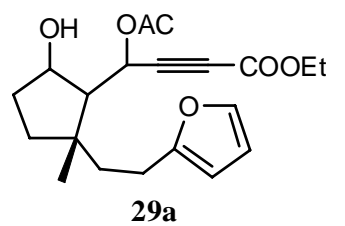

To a solution $29(500 \mathrm{mg}, 1.28 \mathrm{mmol})$ in pyridine $(4 \mathrm{~mL})$ was added acetic anhydride $(3 \mathrm{ml})$ at room temperature, and the reaction mixture was stirred at same temperature for 2 hours. The reaction mixture diluted with ether $(50 \mathrm{~mL})$, and the organic phase was washed with brine $(3 \times 10 \mathrm{~mL})$, and dried over $\mathrm{Na}_{2} \mathrm{SO}_{4}$. The solvent was removed under vacuum and the residue was dissolved in $\mathrm{CH}_{3} \mathrm{CN}(10 \mathrm{~mL})$. To this solution was added pyridine $(0.96 \mathrm{~mL})$ and $\mathrm{HF}(30 \%, 0.96 \mathrm{~mL})$ at $0{ }^{\circ} \mathrm{C}$, and the mixture was stirred at same temperature for 4 hours. The mixture was first diluted with ether (50 $\mathrm{mL})$, and then washed with saturated $\mathrm{NaHCO}_{3}(2 \times 10 \mathrm{~mL})$, brine $(2 \times 10 \mathrm{~mL})$, and dried over $\mathrm{Na}_{2} \mathrm{SO}_{4}$. The solvent was removed under vacuum and the residue purified by flash chromatography on silica gel $(\mathrm{EtOAc} / \mathrm{PE}=1 / 10)$ to give compound 29a $(245 \mathrm{mg}$ in $53 \%$ yields for two steps); ${ }^{1} \mathrm{H}-\mathrm{NMR}\left(400 \mathrm{MH}_{\mathrm{Z}}, \mathrm{CDCl}_{3}\right): \delta$ 7.28-7.26 (m, $\left.1 \mathrm{H}\right), 6.29(\mathrm{~s}, 1 \mathrm{H})$, 6.27-6.25 (m, 1H), 5.99-5.98 (m, 1H), $5.35(\mathrm{~s}, 1 \mathrm{H}), 5.08\left(\mathrm{t}, J_{1}=1.8 \mathrm{~Hz}, J_{2}=5.5 \mathrm{~Hz}, 1 \mathrm{H}\right)$, $4.16(\mathrm{q}, J=7.1 \mathrm{~Hz}), 2.75-2.61(\mathrm{~m}, 2 \mathrm{H}), 2.30(\mathrm{~d}, J=5.8 \mathrm{~Hz}, 1 \mathrm{H}), 2.08(\mathrm{~s}, 3 \mathrm{H}), 2.00-1.95$ $(\mathrm{m}, 2 \mathrm{H}), 1.84-1.80(\mathrm{~m}, 1 \mathrm{H}), 1.68-1.62(\mathrm{~m}, 1 \mathrm{H}), 1.58-1.51(\mathrm{~m}, 2 \mathrm{H}), 1.24(\mathrm{t}, J=7.1 \mathrm{~Hz}$, 3H), $1.07(\mathrm{~s}, 3 \mathrm{H}) ;{ }^{13} \mathrm{C}-\mathrm{NMR}\left(100 \mathrm{MH}_{\mathrm{Z}}, \mathrm{CDCl}_{3}\right): \delta 172.2,169.7,166.7,155.9,140.8$, $110.1,104.6,92.5,90.1,74.7,59.7,57.3,42.8,40.6,38.4,30.3,23.4,21.3,20.9,14.3$; MS $\left[\mathrm{C}_{20} \mathrm{H}_{26} \mathrm{O}_{6}\right],(\mathrm{EI}) \mathrm{m} / \mathrm{z}\left(\mathrm{M}^{+}\right)$, calcd 362, found 362 . 


\section{Preparation of Compound 12}

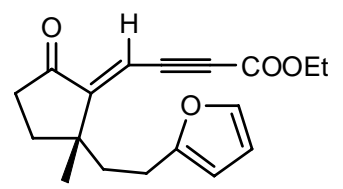

12

To a solution of compound 29a $(210 \mathrm{mg}, 0.58 \mathrm{mmol})$ in anhydrous $\mathrm{CH}_{2} \mathrm{Cl}_{2}(10 \mathrm{ml})$ was added Dess-Martin periodinane $(295 \mathrm{mg}, 0.7 \mathrm{mmol})$, and the mixture was stirred at room temperature for $30 \mathrm{~min}$. The reaction mixture was quenched first with saturated $\mathrm{Na}_{2} \mathrm{~S}_{2} \mathrm{O}_{3}(2.0 \mathrm{~mL})$, and then with aqueous $\mathrm{NaHCO}_{3}(2.0 \mathrm{~mL})$. The mixture was extracted with $\mathrm{CH}_{2} \mathrm{Cl}_{2}(3 \times 15 \mathrm{~mL})$, and the combined organic extracts were dried over anhydrous $\mathrm{Na}_{2} \mathrm{SO}_{4}$. The solvent was removed under vacuum, and the residue was dissolved in anhydrous $\mathrm{CH}_{2} \mathrm{Cl}_{2}(10 \mathrm{ml})$, and then treated with $\mathrm{DBU}(0.09 \mathrm{~mL}, 0.58 \mathrm{mmol})$ at $0^{\circ} \mathrm{C}$ for 2 hours. The reaction mixture was diluted with ether $(50 \mathrm{~mL})$, and the organic phase was washed with brine $(2 \times 10 \mathrm{~mL})$, and dried over $\mathrm{Na}_{2} \mathrm{SO}_{4}$. The solvent was removed and the residue was purified by flash chromatography on silica gel $(\mathrm{EtOAc} / \mathrm{PE}=1 / 10)$ to give compound 12 (106 mg, in 61\% yield for two steps); ${ }^{1} \mathrm{H}-\mathrm{NMR}\left(400 \mathrm{MH}_{\mathrm{Z}}, \mathrm{CDCl}_{3}\right.$ ): $\delta 7.28$ $\left(\mathrm{dd}, J_{1}=0.6 \mathrm{~Hz}, J_{2}=1.8 \mathrm{~Hz}, 1 \mathrm{H}\right), 6.48(\mathrm{~s}, 1 \mathrm{H}), 6.26\left(\mathrm{dd}, J_{1}=1.8 \mathrm{~Hz}, J_{2}=3.1 \mathrm{~Hz}, 1 \mathrm{H}\right)$, $6.00\left(\mathrm{dd}, J_{1}=0.6 \mathrm{~Hz}, J_{2}=3.1 \mathrm{~Hz}, 1 \mathrm{H}\right), 4.29(\mathrm{q}, J=7.2 \mathrm{~Hz}, 2 \mathrm{H}), 2.65(\mathrm{t}, J=8.2 \mathrm{~Hz}, 2 \mathrm{H})$, $2.42(\mathrm{t}, J=8.2 \mathrm{~Hz}, 2 \mathrm{H}), 2.19-2.17(\mathrm{~m}, 1 \mathrm{H}), 2.10-1.72(\mathrm{~m}, 2 \mathrm{H}), 1.77-1.67(\mathrm{~m}, 1 \mathrm{H}), 1.44(\mathrm{~s}$, $3 \mathrm{H}), 1.32(\mathrm{t}, J=7.2 \mathrm{~Hz}, 3 \mathrm{H}) ;{ }^{13} \mathrm{C}-\mathrm{NMR}\left(100 \mathrm{MH}_{\mathrm{Z}}, \mathrm{CDCl}_{3}\right): \delta 205.4,158.1,155.3,153.2$, $140.8,110.2,109.2,104.9,91.7,81.4,62.3,44.5,37.6,35.2,32.1,25.7,23.5,13.9 ; \mathrm{MS}$ $\left[\mathrm{C}_{18} \mathrm{H}_{20} \mathrm{O}_{4}\right]$, (EI) $\mathrm{m} / \mathrm{z}\left(\mathrm{M}^{+}\right)$, calcd 300 , found 300 .

\section{Preparation of 30}

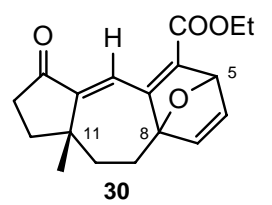

Compound $12(15 \mathrm{mg}, 0.05 \mathrm{mmol})$ was dissolved in toluene $(4 \mathrm{~mL})$, and the solution was refluxed at $120{ }^{\circ} \mathrm{C}$ for 2 hours. The solvent was removed under vacuum, and the residue was purified by flash chromatography on silica gel $(\mathrm{EtOAc} / \mathrm{PE}=1 / 4)$ to give product 30 (12 mg, in 80\% yield); ${ }^{1} \mathrm{H}-\mathrm{NMR}\left(400 \mathrm{MH}_{\mathrm{Z}}, \mathrm{CDCl}_{3}\right): \delta=7.64(\mathrm{~s}, 1 \mathrm{H}), 7.21$ - 
$7.19(\mathrm{~m}, 1 \mathrm{H}), 7.04(\mathrm{~d}, J=5.3 \mathrm{~Hz}, 1 \mathrm{H}), 5.58(\mathrm{~d}, J=1.9 \mathrm{~Hz}, 1 \mathrm{H}), 4.33-4.24(\mathrm{~m}, 2 \mathrm{H}), 2.58-$ $2.37(\mathrm{~m}, 4 \mathrm{H}), 2.09-1.71(\mathrm{~m}, 4 \mathrm{H}), 1.36(\mathrm{t}, J=7.2 \mathrm{~Hz}, 3 \mathrm{H}), 1.27(\mathrm{~s}, 3 \mathrm{H}) ;{ }^{13} \mathrm{C}-\mathrm{NMR}(100$ $\left.\mathrm{MH}_{\mathrm{Z}}, \mathrm{CDCl}_{3}\right): \delta=207.2,163.6,160.6,150.7,149.4,145.2,144.0,120.1,95.7,82.1,60.9$, 44.8, 35.5, 35.2, 35.1, 26.2, 25.7, 14.3; MS [C $\left.{ }_{18} \mathrm{H}_{20} \mathrm{O}_{4}\right]$, (EI) $\mathrm{m} / \mathrm{z}\left(\mathrm{M}^{+}\right)$, calcd 300, found 300 .

\section{Preparation of Compound 31}

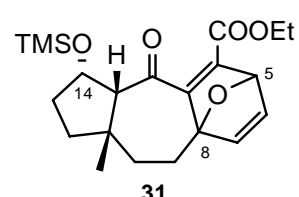

To a solution of $29(705 \mathrm{mg}, 1.80 \mathrm{mmol})$ in anhydrous $\mathrm{CH}_{2} \mathrm{Cl}_{2}(50 \mathrm{ml})$ was added Dess-Martin periodinane $(1.14 \mathrm{~g}, 2.70 \mathrm{mmol})$ at room temperature, and the mixture was stirred at same temperature for 1 hour. The reaction was quenched by addition of saturated $\mathrm{Na}_{2} \mathrm{~S}_{2} \mathrm{O}_{3}(5 \mathrm{~mL})$, followed by aqueous $\mathrm{NaHCO}_{3}(5 \mathrm{~mL})$. The mixture was extracted with $\mathrm{CH}_{2} \mathrm{Cl}_{2}(3 \times 20 \mathrm{~mL})$, and the combined organic extracts were dried over anhydrous $\mathrm{Na}_{2} \mathrm{SO}_{4}$. The solvent was removed under vacuum and the residue was purified flash chromatography $(\mathrm{PE} / \mathrm{EtOAc}=20 / 1)$ to give product $31(210 \mathrm{mg}$, in $30 \%$ yield $)$, together with ca. $60 \%$ yield of uncyclized compounds as a mixture of diastereoisomers; ${ }^{1} \mathrm{H}-\mathrm{NMR}\left(300 \mathrm{MH}_{\mathrm{Z}}, \mathrm{CDCl}_{3}\right): \delta 7.25\left(\mathrm{dd}, J_{1}=2.1 \mathrm{~Hz}, J_{2}=5.4 \mathrm{~Hz}, 1 \mathrm{H}\right), 6.81(\mathrm{~d}, J=5.4 \mathrm{~Hz}$, $1 \mathrm{H}), 5.54(\mathrm{~d}, J=1.8 \mathrm{~Hz}, 1 \mathrm{H}), 4.56(\mathrm{t}, J=4.5 \mathrm{~Hz}, 1 \mathrm{H}), 4.24-4.15(\mathrm{~m}, 2 \mathrm{H}), 2.61(\mathrm{~d}, J=4.5$ $\mathrm{Hz}, 1 \mathrm{H}), 2.44-2.04(\mathrm{~m}, 3 \mathrm{H}), 1.90-1.69(\mathrm{~m}, 5 \mathrm{H}), 1.27(\mathrm{t}, J=7.2 \mathrm{~Hz}, 3 \mathrm{H}), 1.17(\mathrm{~s}, 3 \mathrm{H})$, $0.12(\mathrm{~s}, 9 \mathrm{H}) ;{ }^{13} \mathrm{C}-\mathrm{NMR}\left(75 \mathrm{MH}_{\mathrm{Z}}, \mathrm{CDCl}_{3}\right): \delta 199.7,167.5,162.9,146.2,145.3,144.7$, 95.2, 82.6, 73.6, 65.3, 60.9, 44.0, 40.9, 37.6, 35.1, 25.9, 21.8, 14.3, 0.1; $\mathrm{MS}\left[\mathrm{C}_{21} \mathrm{H}_{30} \mathrm{O}_{5} \mathrm{Si}\right]$, (EI) $\mathrm{m} / \mathrm{z}\left(\mathrm{M}^{+}\right)$, calcd 390 , found 390 .

\section{Preparation of Compound 32}

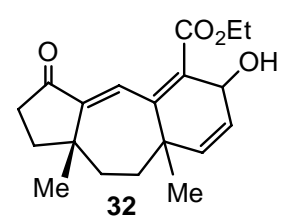

To a solution of $30(30 \mathrm{mg}, 0.10 \mathrm{mmol})$ in $\mathrm{CH}_{2} \mathrm{Cl}_{2}(5 \mathrm{~mL})$ was added $\mathrm{AlMe}_{3}(0.11$ $\mathrm{mL}, 0.22 \mathrm{mmol}$ ) at $-78^{\circ} \mathrm{C}$ in dropwise at $-78^{\circ} \mathrm{C}$, and the reaction mixture was warmed up slowly to $-25^{\circ} \mathrm{C}$, and the reaction mixture was stirred at same temperature for 12 hours. 
The reaction was quenched by addition of aqueous $\mathrm{NH}_{4} \mathrm{Cl}(5 \mathrm{~mL})$, and the mixture was extracted with $\mathrm{Et}_{2} \mathrm{O}(3 \times 10 \mathrm{~mL})$. The combined organic phase was washed with brine (3 x $3 \mathrm{~mL}$ ), and dried over $\mathrm{Na}_{2} \mathrm{SO}_{4}$. The solvent was removed under vacuum and the residue was purified by flash chromatography on silica gel to give product $32(20 \mathrm{mg}$, in $62 \%$ yield); ${ }^{1} \mathrm{H}-\mathrm{NMR}\left(400 \mathrm{MH}_{\mathrm{Z}}, \mathrm{CDCl}_{3}\right): \delta 6.61(\mathrm{~s}, 1 \mathrm{H}), 5.90-5.84(\mathrm{~m}, 2 \mathrm{H}), 4.99(\mathrm{~d}, J=6.5$ Hz, 1H), 4.29-4.23 (m, 2H), 2.59-2.32 (m, 4H), 1.89-1.64 (m, 4H), 1.32 (s, 3H), 1.29 (t, J $=7.1 \mathrm{~Hz}, 3 \mathrm{H}), 1.05(\mathrm{~s}, 3 \mathrm{H}) ;{ }^{13} \mathrm{C}-\mathrm{NMR}\left(100 \mathrm{MH}_{\mathrm{Z}}, \mathrm{CDCl}_{3}\right): \delta 206.5,175.9,147.1,140.8$, $130.9,129.8,129.8,126.9,72.4,61.5,55.3,43.5,37.4,35.9,35.0,32.4,24.6,14.2$, 14.1; DEPT135 for $\mathrm{CH}$ and $\mathrm{CH}_{3} \delta 130.9,129.9,127.0,72.5,24.7,14.3,14.2$; for $\mathrm{CH}_{2}: \delta 61.6$, 37.4, 36.0, 35.1, 32.4; DEPT90 for $\mathrm{CH}: \delta 130.9,129.9,127.0,72.5$; $\mathrm{MS}\left[\mathrm{C}_{19} \mathrm{H}_{24} \mathrm{O}_{4}\right]$, (EI) $\mathrm{m} / \mathrm{z}\left(\mathrm{M}^{+}\right)$, calcd 316 , found 316 .

\section{Preparation of 33}

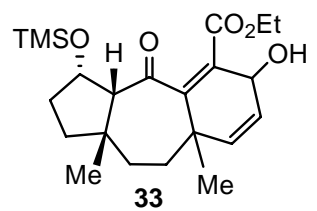

To a solution of $31(92 \mathrm{mg}, 0.23 \mathrm{mmol})$ in $\mathrm{CH}_{2} \mathrm{Cl}_{2}(10 \mathrm{~mL})$ was added $\mathrm{AlMe}_{3}$ $(0.26 \mathrm{~mL}, 0.52 \mathrm{mmol})$ at $-78^{\circ} \mathrm{C}$ in dropwise, and the reaction mixture was slowly warmed up to $-30^{\circ} \mathrm{C}$, and the mixture was stirred at the same temperature for 3 hours. The reaction mixture was then quenched with saturated aqueous $\mathrm{NH}_{4} \mathrm{Cl}(5 \mathrm{~mL})$, was extracted with $\mathrm{Et}_{2} \mathrm{O}(3 \times 15 \mathrm{~mL})$. The combined organic layer was washed brine $(2 \times 3 \mathrm{~mL})$, and dried over $\mathrm{Na}_{2} \mathrm{SO}_{4}$. The solvent was removed and the residue was purified by flash chromatography on silica gel to give product 33 (58 mg, in $61 \%$ yield); ${ }^{1} \mathrm{H}-\mathrm{NMR}$ (400 $\left.\mathrm{MH}_{\mathrm{Z}}, \mathrm{CDCl}_{3}\right): \delta 6.25\left(\mathrm{dd}, J_{1}=5.8 \mathrm{~Hz}, J_{2}=9.4 \mathrm{~Hz}, 1 \mathrm{H}\right), 6.08(\mathrm{~d}, J=9.4 \mathrm{~Hz}, 1 \mathrm{H}), 4.68-$ $4.65(\mathrm{~m}, 1 \mathrm{H}), 4.24-4.13(\mathrm{~m}, 2 \mathrm{H}), 3.93(\mathrm{~d}, J=5.8 \mathrm{~Hz}, 1 \mathrm{H}), 2.70(\mathrm{~d}, J=4.4 \mathrm{~Hz} 1 \mathrm{H}), 2.65-$ $2.49(\mathrm{~m}, 2 \mathrm{H}), 2.05-1.55(\mathrm{~m}, 6 \mathrm{H}), 1.39$ (s, 3H), $1.26(\mathrm{t}, J=7.1 \mathrm{~Hz}, 3 \mathrm{H}), 1.16(\mathrm{~s}, 3 \mathrm{H}), 0.16$ $(\mathrm{s}, 9 \mathrm{H}) ;{ }^{13} \mathrm{C}-\mathrm{NMR}\left(100 \mathrm{MH}_{\mathrm{Z}}, \mathrm{CDCl}_{3}\right): \delta 207.4,174.3,139.8,136.7,131.6,129.2,74.9$, 69.7, 63.2, 61.1, 52.7, 43.6, 40.6, 40.5, 32.5, 32.4, 23.5, 20.6, 14.0, 1.8; MS [ $\left.\mathrm{C}_{22} \mathrm{H}_{34} \mathrm{O}_{5} \mathrm{Si}\right]$, (EI) $\mathrm{m} / \mathrm{z}\left(\mathrm{M}^{+}\right)$, calcd 406, found 406. 


\section{D NMR Study for Compound 34}

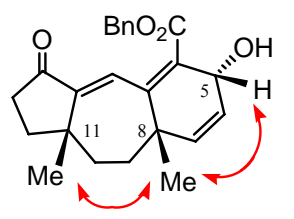

34

In the $\mathrm{H}^{1}$-NMR spectra of compound 32 and 33, the methyl group of ethyl ester presents their signals from their range between $\delta 1.0-1.5$, which cause the signal overlap with the methyl groups at $\mathrm{C}_{11}$ and $\mathrm{C}_{8}$ at core. To simplify the 2D-NMR study, we decided to use compound 34 to do the 2D-NMR study. To this end, we had synthesized compound 34 from 36 in 4 steps, and its detail synthesis will be discussed in our future report.

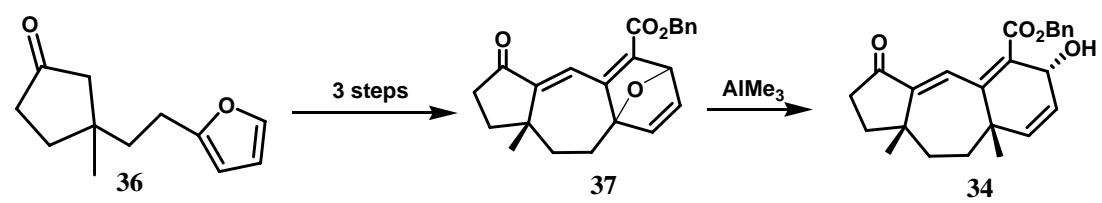

The following description illustrated the detail for the 2D-NMR study:

In NMR spectra, the oscillating waves flanking the strong peaks are truncation artifacts, which appear when the acquisition time is relative short and thus the signal of strong peaks remaining strong at the end of the collected fid. Although kinds of mathematical methods such as many window functions have been designed to overcome truncation artifacts, the basic and reliable way is to extend the acquisition time. Ordinarily, acquisition time over $3 \mathrm{~T}_{2}$ is sufficient to suppress truncation artifacts.

As the spectrum width is the reverse of the interval between two successively recorded complex points in the fid

$$
\mathrm{SW}=1 / \triangle \mathrm{t}
$$

SW: Spectrum width

$\triangle \mathrm{t}$ : Interval between two successively recorded complex points in the fid and the acquisition time is the result of the total number of recorded complex points multiplying the interval:

$$
\mathrm{AQ}=\mathrm{N}^{*} \triangle \mathrm{t}
$$

AQ: Acquisition time

$\mathrm{N}$ : the total number of recorded complex points 
Two ways can be applied to extend the acquisition time: the first is getting more points along the fid in a predefined spectrum width and the second is to extend the interval between two successively recorded complex points with a predefined number of recorded complex points. It is not difficult to get suitable acquisition time in directly detected dimension (getting more points along the fid in a predefined spectrum width will not greatly increase the experiment time); while it is not easy to get more acquisition time by getting more points in the in directly detected dimension due to limited experiment time. So the second way is applied in the indirectly detected dimension, which will not greatly increase the experiment time, but will narrow the spectrum width and give higher resolution to the spectrum because of more complex points located in per ppm. As the spectrum width in indirectly detected dimension is narrowed, the signals outside the spectrum width will be aliased into the spectrum in our States-TPPI indirectly detection mode (see: John Cavanagh, Wayne J. Fairbrother, Arthur G. Palmer III and Nicholas J. Skelton, Protein NMR Spectroscopy, Principles and Practice, 1996, Academic Press, San Diego.).
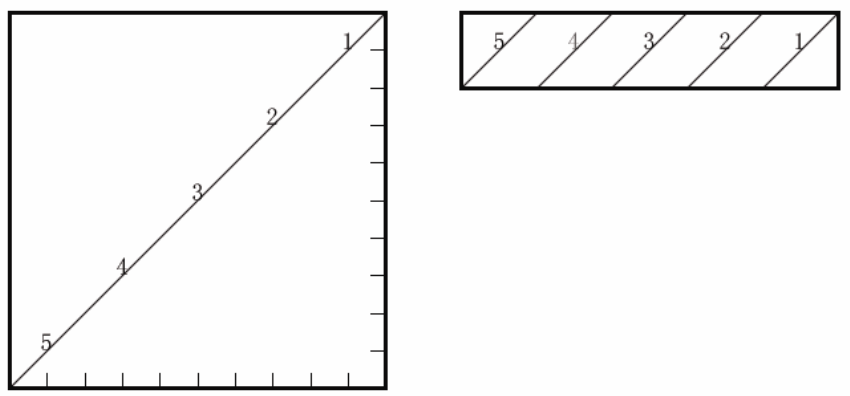

left: the whole NMR spectrum

right: the aliased spectrum due to narrowed SW in the indirect dimension.

In the detected Compound 34 sample, the two methyl groups are too close in chemical shift, so the cross peaks of these two methyl groups are located near to the diagonal peaks. The truncation artifacts of the strong diagonal peaks will severely affect the cross peaks of the two methyl groups or even completely suppress the cross peaks in the indirect dimension. Our idea to suppress truncation artifacts and make the cross peaks clearer is the based on the second method mentioned above. 

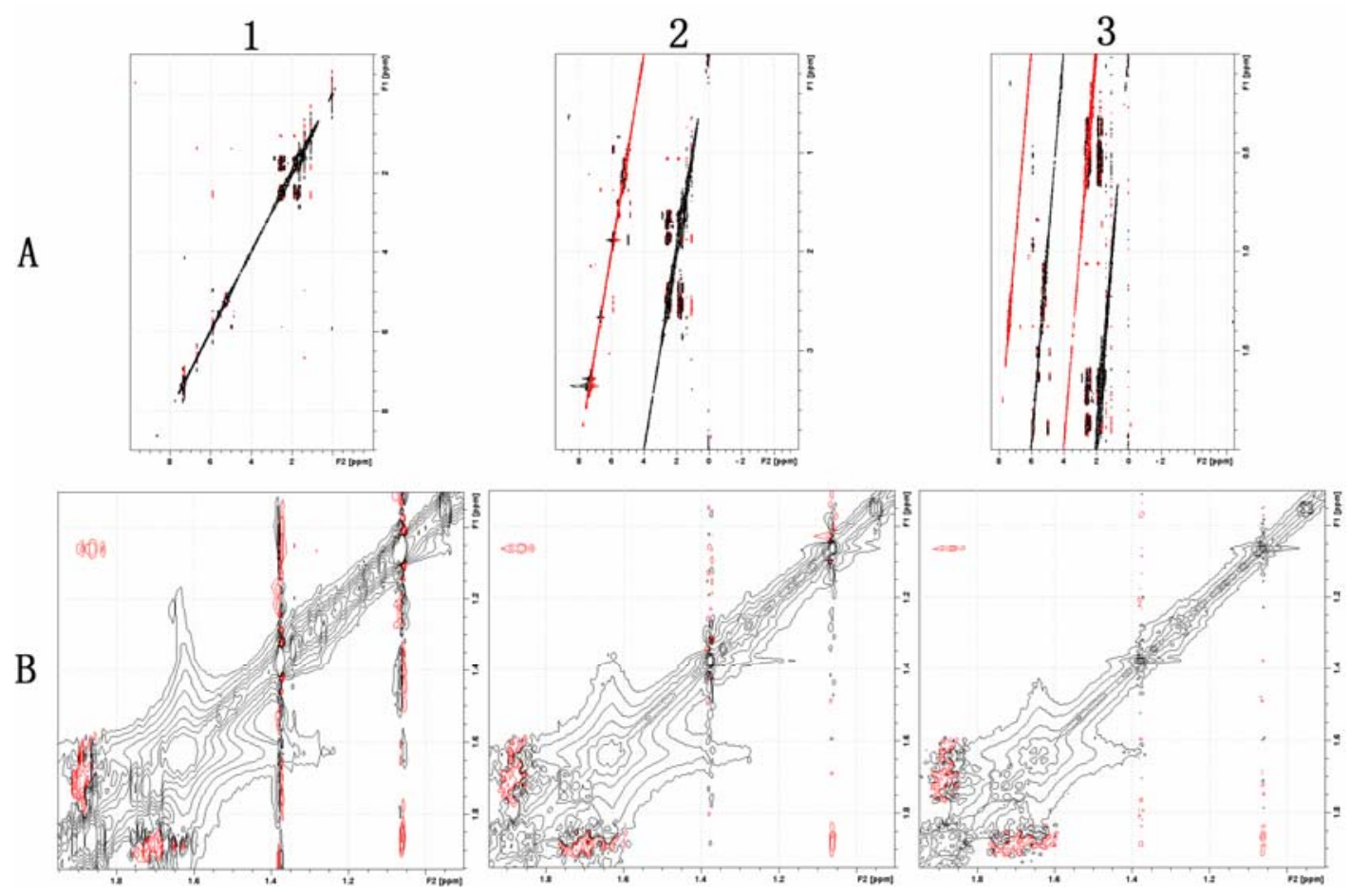

All the 2D-noesy spectra finished with mixing time $200 \mathrm{~ms}$ and 256 complex points in the indirect dimension

A: the three spectra transformed from collected fids

B: the three zoomed in areas around the two $\mathrm{CH}_{3}$ groups (Scaling the cross peak located at the left top to the same height level)

1: $\mathrm{SW}=10 \mathrm{ppm}$, the center is at $4 \mathrm{ppm}, \mathrm{AQ}=0.0640 \mathrm{~s}$, resolution $=7.82 \mathrm{~Hz}$ without alias in indirect dimension, but serious truncation artifacts flanking the strong $\mathrm{CH}_{3}$ group diagonal peaks;

2: $\mathrm{SW}=4 \mathrm{ppm}$, the center is at $2 \mathrm{ppm}, \mathrm{AQ}=0.1599 \mathrm{~s}$, resolution $=3.13 \mathrm{~Hz}$ with alias in indirect dimension, less truncation artifacts flanking the strong $\mathrm{CH}_{3}$ group diagonal peaks;

3: $\mathrm{SW}=2 \mathrm{ppm}$, the center is at $1 \mathrm{ppm}, \mathrm{AQ}=0.3199 \mathrm{~s}$, resolution $=1.56 \mathrm{~Hz}$ with more alias in indirect dimension, least truncation artifacts flanking the strong $\mathrm{CH}_{3}$ group diagonal peaks. 